\title{
Impact of COVID-19 on elderly care
}

\section{To the Editor,}

As of April 2020, $>95 \%$ of COVID-19 deaths are among older people aged $>60$ years, and nearly half of the deaths occurred in those aged $\geq 80$ years. ${ }^{1}$ Older adults generally have underlying health problems (such as cardiovascular disease, diabetes, and respiratory illness) that weaken the immune system and increase the risk of COVID-19 infection. ${ }^{2}$ Outbreaks may occur in elderly care centres and spread to the community. ${ }^{3}$

On 7 July 2020, the first confirmed case in Hong Kong involving elderly centres occurred at Tsz Wan Shan Kong Tai Care for the Aged Centre. The confirmed cases nearly double within 2 days, involving 23 older adults. As of 17 July 2020, there were 44 confirmed cases. ${ }^{4}$ Outbreak also appeared in elderly centres at Kwai Chung, Tuen Mun, and Sham Shui Po districts.

To reduce the risk of infection, the Elderly Services Association of Hong Kong and Centre for Health Protection ${ }^{5}$ recommended six measures: (1) prohibiting family members from visiting and older people from going out; (2) monitoring of older people's health while going to public hospitals for regular checking. If follow-up consultation and medication are required, a visiting doctor should be arranged; (3) testing of COVID-19 virus for staff; (4) minimising group activities or gatherings to maintain social distancing, and strictly limiting the proportion of older people to staff in group activities to $1: 1$ or $1: 2$; (5) spraying an anti-virus coating; ${ }^{6}$ and (6) wearing a face mask and washing hands with alcohol-based sanitiser frequently.

These measures may result in social isolation and loneliness, increasing the risk of anxiety and depression. To mitigate this, family members should utilise social media and video communication applications to maintain social connections. These measures may also lead to poor physical and mental health, resulting in increased blood pressure, heart disease, and obesity and diminished immune system functioning, as well as Alzheimer's disease. ${ }^{7}$ Older people can be taught Tai-Chi and Baduanjin to relax and improve the respiratory movement, rhythm, and pattern and to enhance the immune system and physical and mental health to prevent anxiety and depression. ${ }^{8}$

\section{Siukan Law ${ }^{1}$, Albert Wingnang Leung ${ }^{2}$, Chuanshan $\mathrm{Xu}^{3}$ \\ 1 Department of Science, School of Science and Technology, The Open University of Hong Kong, Hong Kong \\ 2 School of Graduate Studies, Lingnan University, Hong Kong \\ 3 Key Laboratory of Molecular Target and Clinical \\ Pharmacology, State Key Laboratory of Respiratory Disease, School of Pharmaceutical Sciences \& Fifth Affiliated Hospital, Guangzhou Medical University, China}

Correspondence to: Dr Siukan Law, Department of Science, School of Science and Technology, The Open University of Hong Kong, Ho Man Tin, Kowloon, Hong Kong.

Email: siukanlaw@hotmail.com

\section{REFERENCES}

1. Yanez ND, Weiss NS, Romand JA, Treggiari MM. COVID-19 mortality risk for older men and women. BMC Public Health 2020;20:1742. Crossref

2. Tahaghoghi-Hajghorbani S, Zafari P, Masoumi E, et al. The role of dysregulated immune responses in COVID-19 pathogenesis. Virus Res 2020;290:198197. Crossref

3. Brown KA, Jones A, Daneman N, et al. Association between nursing home crowding and COVID-19 infection and mortality in Ontario, Canada. JAMA Intern Med 2021;181:229-236. Crossref

4. Wong P. The first confirmed case in Hong Kong involving residential care homes for the elderly is located at Tsz Wan Shan. https://news.rthk.hk/rthk/ch/component/k2/1536336-20200707. htm?spTabChangeable $=0$. Accessed 20 October 2020.

5. Centre for Health Protection. Guidelines for Residential Care Homes for the Elderly or Persons with Disabilities for the Prevention of Coronavirus Disease (COVID-19). https://www. chp.gov.hk/files/pdf/advice_to_rche_rchd_on_prevention_of_ nid_eng.pdf. Accessed 20 October 2020.

6. Wu B. Social isolation and loneliness among older adults in the context of COVID-19: a global challenge. Glob Health Res Policy 2020;5:27. Crossref

7. Jahnke R, Larkey L, Rogers C, Etnier J, Lin F. A comprehensive review of health benefits of qigong and tai chi. Am J Health Promot 2010;24:e1-e25. Crossref

8. Feng F, Tuchman S, Denninger JW, Fricchione GL, Yeung A. Qigong for the prevention, treatment, and rehabilitation of COVID-19 infection in older adults. Am J Geriatr Psychiatry 2020;28:812-9. Crossref 